Vertebrate palaeontology

\section{Rauisuchians and the success of dinosaurs}

\section{from Michael Benton}

THROUGHOUT most of the Triassic period (245-208 Myr), and before the age of the dinosaurs, the top carnivores were a group of reptiles called rauisuchians. Although this group was formerly thought to have had a restricted distribution, recent papers prove that its distribution was in fact worldwide ${ }^{1-8}$. More provocatively, some of the new work suggests the need to modify commonly held views about both the evolution of reptiles in the Triassic and the origin of the dinosaurs.

The Rauisuchia were archosaurs (the group of reptiles that also includes dinosaurs and crocodiles) and belonged to the basal group, the 'Thecodontia'. Several of them - such as Poposaurus, Teratosaurus and numerous unnamed forms that have been identified on the basis of isolated teeth and jaws ${ }^{2,3}$ - were formally classified as dinosaurs. In fact, a whole assemblage of fictitious carnivorous dinosaurs - the Teratosauridae - was founded upon middle and late Triassic rauisuchian teeth and the skeletons of prosauropod dinosaurs $\mathrm{s}^{9,10}$. The oldest known true dinosaurs occurred in the middle of the late Triassic (about $225 \mathrm{Myr}$ ), and would have been preyed upon by rauisuchians. It has been suggested that rauisuchians were ancestral to (some) dinosaurs ${ }^{1}$, but that is unlikely because of their specialized ankles, pelvis and skull. The rauisuchians died out at the end of the Triassic without leaving any descendants, that is as far as we can tell.

Rauisuchians are characterized by several derived characters of the skull (for

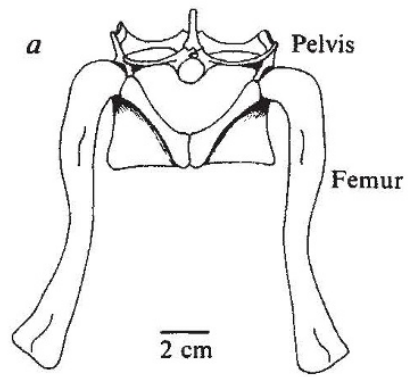

example, keyhole-shaped antorbital fenestra, movable joints and extra slot-like fenestra between the premaxilla and maxilla) and pelvis (acetabulum faces ventrally, low ilium, pubis antero-ventral to ilium). There are two families, the quadrupedal Rauisuchidae and the bipedal Poposauridae. A typical late Triassic rauisuchid, Saurosuchus (Fig.1), was 6-7 m long, with a massive skull, short neck, fairly long limbs and a powerful tail.

What is of more importance, from the point of view of archosaur evolution in the Triassic and, in particular, theories about the origin and success of the dinosaurs, is new work showing rauisuchians had an erect gait $^{2,3}$. The standard view is that advances in the limb posture of archosaurs during the Triassic explain why dinosaurs were so successful. The early Triassic archosaurs had a primitive sprawling posture, like that of living lizards and salamanders. The posture of archosaurs supposedly became semi-erect in the middle Triassic, and finally dinosaurs, with their limbs tucked right under the body, emerged in the Triassic".

The erect posture is commonly thought to have allowed increased running speed, agility and size, allowing these animals to outcompete all manner of other tetrapods in the middle and late Triassic ${ }^{12}$. However, as I have previously argued ${ }^{13}$, large-scale 'competition' of this kind between highlevel taxonomic groups and spread over tens of millions of years is most unlikely. More probably, the dinosaurs radiated opportunistically only after the extinction of earlier dominant groups (mammal-like reptiles, rhynchosaurs, thecodontians). Further weight is given to this view by the fact that rauisuchians had an erect gait and yet were replaced by the dinosaurs.

Dinosaurs and rauisuchians achieved an erect gait in different ways. In a primitive sprawling reptile, the thigh bone (femur) sticks out roughly sideways, and the head of the femur fits straight into the sidewaysfacing bowl-shaped pelvic socket. In an erect animal, the femur points straight down, and changes have to occur at the joint between femur and pelvis. In dinosaurs (and in mammals), the femur develops a head at right angles to its shaft (Fig.1a). In rauisuchians, on the other hand, the pelvis is tipped over, so that the pelvic socket faces downwards instead of sideways (Fig. 1b). Recently, it has become evident that erect gait was also achieved by a third group of archosaurs - the saltoposuchid crocodilomorphs, distant relatives of the living crocodiles ${ }^{14}$. In the late Triassic, then, three archosaur lineages showed independently derived advances in locomotion, and yet only the dinosaurs survived - the other two lineages died out by the end of the Triassic.

1. Chatterjee, S. Nature 295, 317 (1982).

2. Bonaparte, J.F. Rev. Mus. Argent. Cienc. nat. Paleont. 3, 55 (1981).

3. Bonaparte, J.F. J. vert. Paleont. 3, 210 (1984).

4. Ochev, V.G. Paleont, J. 1982, 210 (1982).

5. Pinna, G. \& Arduini, P. Natura, Milano 69, 73 (1978).

6. Wild, R. Mesozoic vert. Life 1, 15 (1980).

7. Dawley, R.M., Zawiskie, J.M. \& Cosgriff, J.W. J. Paleont. 53, 1428 (1979).

8. Dutuit, J.-M. Annls paleont, vert. 65, 55 (1979).

9. Walker, A.D. Phil. Trans. R. Soc. B248, 53 (1964)

10. Benton, M.J. Abstr. 3rd Symp. Mesozoic terrest. Ecosyst. (in the press).

11. Charig, A.J. in Studies in Vertebrate Evolution (eds Joysey, K.A. \& Kemp, T.S.) 121 (Oliver \& Boyd, Edinburgh, 1972).

12. Charig. A.J. Mém. Soc. géol. Fr. 139, 207 (1980); Symp. zool. Soc. Lond. 52 (in the press).

13. Benton, M.J. Q. Rev. Biol. 58, 29 (1983); Nature 302, 16 (1983).

14. Crush, P.J. Paleontology 27, 131 (1984).

Michael Benton is at the University Museum, Parks Road, Oxford OXI 3PW.
Fig.1 Rauisuchians, giant meat-eaters of the Triassic. $a, b$, Hindlimbs and pelvis of an early 'dinosaur' $(a)$ and Saurosuchus $(b)$ viewed from behind. $c$, Saurosuchus from the late Triassic of Argentina, 6-7m long. Both dinosaurs and rauisuchians had erect gait, but this advance was achieved in different ways in each group: a bent head on the femur in dinosaurs $(a)$ and a horizontal pelvic socket in rauisuchians $(b)$. From refs 2,3 .
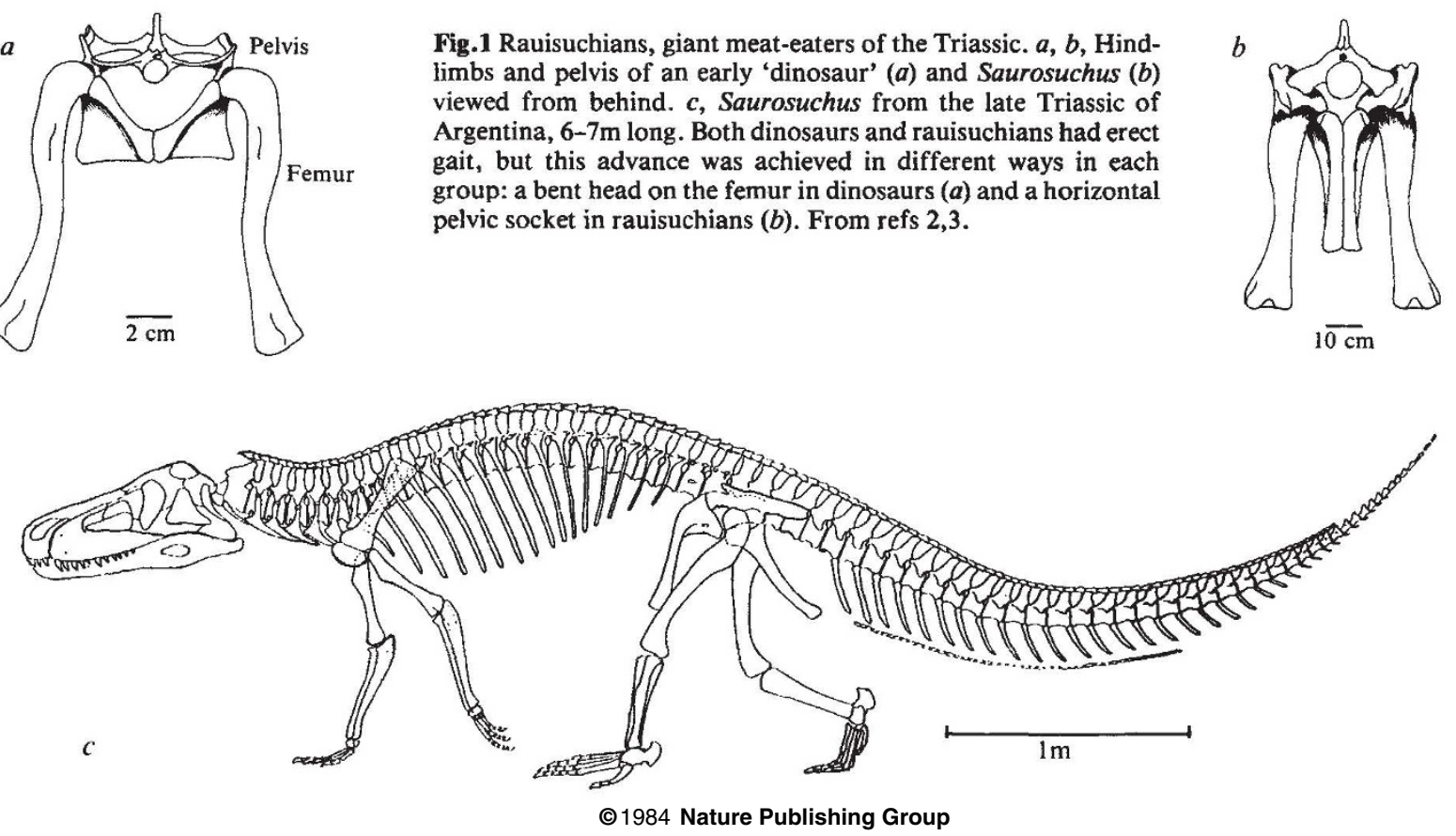